\title{
THE IMPACT OF WORKPLACE SPIRITUALITY ON ORGANIZATIONAL CITIZENSHIP BEHAVIOR: THE ROLES OF ORGANIZATIONAL IDENTIFICATION AND PERCEIVED ORGANIZATIONAL SUPPORTS
}

\author{
Syayyidah Maftuhatul Jannah a \\ Claudius Budi Santoso ${ }^{b}$ \\ ab Universitas Gadjah Mada, Indonesia \\ Corresponding email: bsantoso@ugm.ac.id
}

\begin{abstract}
This study is aimed at the examination of the relationship of workplace spirituality and organizational citizenship behavior with the roles of organizational identification and perceived organizational supports as moderating variables. This study uses affective events theory to explain that workplace sprituality produces positive affective and then encourages organizational citizenship behavior. Meanwhile, the roles of organizational identification and perceived organizational supports that relationship based on social identity theory and social exchange theory subsequently. This study conducts survey methods and purposive sampling methods in collecting primary data from respondents working in local government institusions, then the primary data is processed with moderated regression model. The result reveals that workplace spirituality positively affected organizational citizenship behavior. But, organizational identification and perceived organizational support are significant, but have not moderated the relationship of workplace spirituality and organizational citizenship behavior. This study suggests that the measurement of organizational identification also has to consist of pride or emotional attatchment to organizations. Meanwhile, the measurement of perceived organizational supports has to insert dimensions of procedural justice and supervisor support, not only dimensions of rewards and employee's well-being. In addition, dispositional factors could be more influential to be a moderating variable on that relationship. In conclusion, creating the climate of workplace spirituality and having employees' trust to their organization are more critical to increase organizational citizenship behavior, especially in local, public organizations.
\end{abstract}

Keywords: Workplace Spirituality, Organizational Citizenship Behavior, Organizational Identification, Perceived Organizational Support

\section{Introduction}

Workplace spirituality was called employees experience in the workplace (Meezenbroek, et al., 2012; Porshariati, et al, 2014). When employees can express their desire for caring and having compassion to others, experiencing inner consciousness in the pursuit of meaningful work and that enables transcendence, so it can be said that the employees have a positive experience while in the workplace. This will make the employees work with pleasure and even do other positive things that exceed their obligations (job description) in the workplace (F.Kazemipour, et al., 2012). Hence, studies reveal that workplace spirituality benefits an increasing of organizational citizenship behavior.

In fact, the previous studies have shown varied results on the relationship of workplace spirituality and organizational citizenship behavior. Other previous studies state that workplace spirituality negatively affects on organizational citizenship behavior (F.Kazemipour, et al., 2012; Nasurdin, et al., 2013). In particular, dimension of sense of community on workplace spirituality has positive influence on organizational citizenship behavior organizational citizenship behavior (Milliman, et al, 2003), but another study 


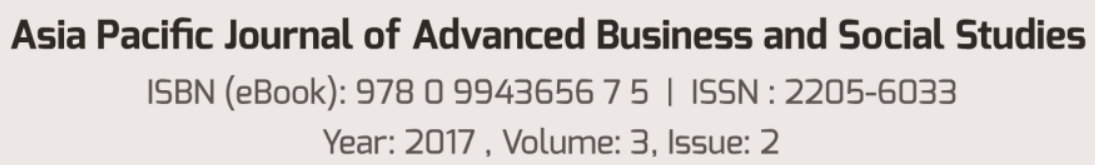

demontrates that workplace spirituality has not significantly affected on organizational citizenship behavior (F.Kazemipour, et al., 2012).

This study argues that organizational factors or dispositional factors enable to control the relationship of workplace spirituality and organizational citizenship behavior. This study proposes perceived organizational support and organizational identification as moderating variables. This study perceives that when individuals experience organizational support, it enhances positive feeling and, at the end, it will strengthen the relationship of workplace spirituality and organizational citizenship behavior. Also based on social identity theory, when an individual feels they have similarity with an organization, it raises positive affectivity, and hence, this feeling improves the degree of the relationship of workplace spirituality and organizational citizenship behavior.

\section{Hypotheses Development}

\section{The Influence of Workplace Spirituality On Organizational Citizenship Behavior}

The influence of workplace spirituality on organizational citizenship behavior can be explained based on Affective Event Theory (AET). According to AET, an event is a proxy that causes affective reactions (Weiss \& Cropanzano, 1996). When employees can express their desire for caring and having compassion to others, experiencing inner consciousness in the pursuit of meaningful work, that enables transcendence, so it can be said that the employees have a positive experience while in the workplace. This positive experience will make the employees work with pleasure and even do other positive things that exceed their obligations (job description) in the workplace (F.Kazemipour, et al., 2012). Here, individuals experiencing spirituality in workplace voluntarily increase organizational citizenship behavior.

H1: Workplace spirituality affects organizational citizenship behavior positively.

\section{Organizational Identification Moderates The Influence of Workplace Spirituality on Organizational Citizenship Behavior}

Organizational identification occurs when employees perceive oneness with their employing organization (He \& Brown, 2013). Based on social identity theory, when employees identify their self toan organization, they have a positive attitude to their organization. Since, employees who identify their self to an organization consider the welfare of organization as a priority, they will be more likely to work in accordance with the goal of the organization Duncan, Pontes, \& Griffiths, 2014). Then, high organizational identification will strengthen the influence of workplace spirituality on organizational citizenship behavior

H2: Organizational identification moderates affect workplace spirituality on organizational citizenship behavior. The higher organizational identification, the stronger positive affects workplace spirituality on organizational citizenship behavior.

\section{Perceived Organizational Support Moderates The Influence of Workplace Spirituality On Organizational Citizenship Behavior}

Perceived organizational support is that employees perceive that the organization support and care for their well-being (Chinomona, 2011; Chênevert, et al., 2014). Organizational support enables a raise individual positive behavior in the workplace (Chinomona, 2011). The employee with high perceived organizational support experience higher job involvement and relate to others as required by the job (Kahn, 1990 in Mishra, 2013. Then, based on 
social exchange theory, individuals tend to increase their willingness to do extra-role behavior for organizational purposes. Hence, the higher perceived organizational support will strengthen the influence of workplace spirituality on organizational citizenship behavior.

H3: Perceived organizational support moderates affect workplace spirituality on organizational citizenship behavior. The higher perceived organizational support, the stronger positive affects workplace spirituality on organizational citizenship behavior.

\section{Research Method}

Population in this study is the employees who work in local government institutions. The criteria of respondents is who have worked at least two years. Workplace spirituality use 22 items (Petchsawang \& Duchon, 2009). Organizational citizenship behavior uses 18 items (Organ \& Ryan, 1995). Organizational identification uses 6 items (Mael \& Ashforth, 1992). Perceived organizational support uses 8 items (Eisenberger, 1986). The collected data is tested by moderated regression analysis.

\subsection{The Results}

Table 1: Descriptive Statistic

\begin{tabular}{llllllllll}
\hline Variable & $\begin{array}{l}\text { Me } \\
\text { an }\end{array}$ & SD & $\mathbf{1}$ & $\mathbf{2}$ & $\mathbf{3}$ & $\mathbf{4}$ & $\mathbf{5}$ & $\mathbf{6}$ & $\mathbf{7}$ \\
\hline Control & & & & & & & & & \\
& 46,8 & 0,87 & & & & & & & \\
1. Age & 1 & 7 & & & & & & & \\
& & 0,49 & - & & & & & & \\
2. Gender & 0,41 & 3 & $0,186^{*}$ & & & & & & \\
3. & & 0,60 & & 0,11 & & & & & \\
Education & 2,79 & 5 & 0,143 & 4 & & & & & \\
& 17,6 & & 0,587 & 0,0 & & & & & \\
4. Tenure & 8 & 0,94 & $* *$ & 28 & 0,027 & & & & \\
\hline & & 0,35 & & 0,13 & 0,209 & 0,0 & & & \\
5. WS & 3,14 & 4 & 0,41 & 9 & $* *$ & 02 & & & \\
& & 0,36 & & 0,05 & & 0,0 & 0,340 & & \\
6. OCB & 3,67 & 5 & 0,58 & 3 & 0,081 & 01 & $* *$ & & \\
& & 0,49 & & 0,0 & 0,209 & 0,15 & & 0,387 & \\
7. OI & 3,29 & 8 & 0,101 & 81 & $* *$ & 1 & 0,007 & $* *$ \\
& & & & 0,10 & & 0,11 & 0,429 & $0,301^{*}$ & 0,230 \\
8. POS & 3,42 & 0,68 & $0,170^{*}$ & 2 & 0,074 & 4 & $* *$ & $*$ & $* *$ \\
\hline
\end{tabular}

WS=workplace spirituality; $\mathrm{OCB}=$ organizational citizenship behavior;

$\mathrm{OI}=$ organizational identification; POS=perceived organizational support

\section{Hypotheses Testing}

Table 2: The Influence Workplace Spirituality On Organizational Citizenship Behavior

\begin{tabular}{|c|c|c|}
\hline Variable & Model 1 & Model 2 \\
\hline Control & & \\
\hline Age & 0,127 & 0,132 \\
\hline Gender & 0,069 & 0,115 \\
\hline Education & 0,089 & $0,165^{*}$ \\
\hline Tenure & $-0,073$ & $-0,077$ \\
\hline
\end{tabular}

Independent 
$\mathbf{0 , 3 8 5}$

\begin{tabular}{ccc}
\hline WS & & $\mathbf{0 , 3 8 5 ^ { * }}$ \\
\hline & & \\
\hline Adjusted & $-0,007$ & $\mathbf{0 , 1 3 1}$ \\
& $-0,007$ & 0,138 \\
F & 0,720 & $5,792^{*}$ \\
\hline
\end{tabular}

a. Dependent Variable: OCB

$\mathrm{N}=160 ;{ }^{*} p<0,05$; the value shown is standardized coefficient

Table 3. The Result of Hypothesis Testing Moderator (Organizational Identification)

On The Influence Workplace Spirituality to Organizational Citizenship Behavior

\begin{tabular}{|c|c|c|c|c|}
\hline Variabl & Model 1 & Model 2 & Model 3 & Model 4 \\
\hline \multicolumn{5}{|l|}{ Control } \\
\hline Age & 0,120 & 0,127 & 0,113 & 0,121 \\
\hline Gender & 0,076 & 0,120 & 0,091 & 0,090 \\
\hline Education & 0,085 & $0,161^{*}$ & 0,084 & 0,083 \\
\hline Tenure & $-\mathbf{0 , 0 5 7}$ & $-0,063$ & $-0,003$ & $-0,008$ \\
\hline \multicolumn{5}{|l|}{ Independent } \\
\hline WS & & $\mathbf{0 , 3 8 0 *}$ & $0,360^{*}$ & $0,356^{*}$ \\
\hline \multicolumn{5}{|l|}{ Moderator } \\
\hline IO & & & $\mathbf{0 , 3 6 6 ^ { * }}$ & $0,367^{*}$ \\
\hline \multirow{2}{*}{\multicolumn{5}{|c|}{ Effect }} \\
\hline Interaction & & & & \\
\hline WS x OI & & & & $\mathbf{0 , 0 4 4}$ \\
\hline \multirow[t]{2}{*}{ Adjusted } & $-0,008$ & 0,127 & 0,250 & $\mathbf{0 , 2 4 7}$ \\
\hline & $-0,008$ & o,135 & 0,115 & 0,132 \\
\hline $\mathbf{F}$ & 0,703 & $5,586^{*}$ & $9,789^{*}$ & $8,415^{*}$ \\
\hline
\end{tabular}

a. Dependent Variable: OCB

$\mathrm{N}=160 ;{ }^{*} p<0,05$; the value shown is standardized coefficient

Table 4. The Result of Hypothesis Testing Moderator (Perceived Organizational Support)

On The Influence Workplace Spirituality On Organizational Citizenship Behavior

\begin{tabular}{lllll}
\hline Variable & Model 1 & Model 2 & Model 3 & Model 4 \\
\hline Control & & & & \\
Age & 0,120 & 0,127 & 0,105 & 0,118 \\
Gender & 0,076 & 0,120 & 0,124 & 0,134 \\
Education & 0,085 & $0,161^{*}$ & $0,155^{*}$ & $0,151^{*}$ \\
Tenure & $-\mathbf{0 , 0 5 7}$ & $-0,063$ & $-0,072$ & $-0,080$ \\
\hline Independent & & & & \\
WS & & $\mathbf{0 , 3 8 0 ^ { * }}$ & $0,305^{*}$ & $0,295^{*}$ \\
\hline $\begin{array}{l}\text { Moderator } \\
\text { POS }\end{array}$ & & & \\
\hline
\end{tabular}

\section{Effect}

\section{Interaction}

WS x POS

\begin{tabular}{|c|c|c|c|c|}
\hline $\operatorname{MNS}$ & & & & 0,114 \\
\hline Adjusted & $-0,008$ & 0,127 & 0,147 & 0,154 \\
\hline & $-0,008$ & 0,135 & 0,012 & 0,142 \\
\hline $\mathbf{F}$ & 0,703 & $5,586^{*}$ & $5,528^{*}$ & $5,101^{*}$ \\
\hline
\end{tabular}


a. Dependent Variable: OCB

$\mathrm{N}=160 ;{ }^{*} p<0,05$; the value shown is standardized coefficient

\section{Discussion}

Hypothesis 1 is supported significantly. Workplace spirituality can encourage transcendence experience of employees through work processes anda sense of connectedness with others that can bring happiness (Petchsawang \& Duchon, 2009). The employee who has spirituality in the workplace can be said to have a purposethat is greater than themselves, therefore they will play a role and contribute more to others of the wider community (Mitroff \& Denton, 1999; Ashmos \& Duchon, 2000, in Chinomona, 2011). Moreover, spirituality in the workplace makes employees more likely to carry their entire self (physically, mentally, emotionally, and spiritually) at work, so they can have more commitment in working, responsible in helping achieve the objectives of the organization and even do other positive things that go beyond what is intheir job description (F.Kazemipour, et al., 2012).

Hypothesis 2 is not supported. It means that organizational identification has no role as a moderating variable on the the effect of workplace spirituality on organizational citizenship behavior. The employees have not shown high emotional attachment to local government institutions. Second, this suggested that membership in an organization is either voluntary or defined, but social identity is a personal choice as results of their attitude towards their organization (Lewin, 1997 in Goodman, 2002 ). Group members tend to identify themselves with their group (organization), when the group (organization) has a high profile, which contributes to high self-esteem (Cialdini, et al, 1976; Ellemers, et al, 1988 in Goodman, 2002). In fact, local government institutions might not have contributed to improving selfesteem of the members. Hence, it can result that the employees do not identify themselves to local governments instituions.

Hypothesis 3 also is not supported. It means that perceived organizational support as moderator has no effect on the relationship of workplace spirituality on organizational citizenship behavior. Based on organizational support theory, fairness, supervisor support, and organizational rewards and job conditions are stated enabling to increase perceived organizational support (Eisenberger et al., 1986 in Rhoades \& Eisenberger, 2002. However, this study only uses organizational rewards and job conditions (Eisenberger et al., 2002 in Purbo, 2015), which are less powerful than procedural justice and supervisor support to produce perceived organizational supports (Rhoades \& Eisenberger, 2002).

Second, theories of organizational support theories (Eisenberger et al, 1986; Shore \& Shore, 1995 in Rhoades \& Eisenberger, 2002) focused on organizational actions, without considering the influence of individual personality (emotional responses) on organizational supports (Watson \& Clark, 1984 in Rhoades \& Eisenberger, 2002). Employees with negative attitude to their organizations will have negative perception towards supportive organizational treatments.

The result of this study bring some practical implication, especially for public organizations. First, creating the atmosphere of sprituality in the workplace and having employees positive attitude to organizations are critical to encourage positive extra-role behavior, instead of relying on supplying supportive organizational actions. Second, employees trust to organizations is also very important to create organizational citizenship behavior. Third, the use of factors perceived be more influential for perceived organizational supports has to be main consideration for the relevant study. Finally, since organizational identification and perceived organizational supports have not successfully acted as moderating variables, this study propose that dispositional factors, such as personality or traits, could be more effective to influence the relationship of workplace spirituality and organizational citizenship 


\section{Asia Pacific Journal of Advanced Business and Social Studies \\ ISBN (eBook): 9780994365675 I ISSN : 2205-6033 \\ Year: 2017, Volume: 3, Issue: 2}

behavior. The dimensions of compassion, mindfulness, and transcendence in workplace sprituality address the importance of individuals personality or traits. 


\section{References}

i. Ahmad, A. \& Omar, Z., 2014. Reducing Deviant Behavior through Workplace Spirituality and Job Satisfaction. Asian Social Science, 10(19), pp. 107-112.

ii. C.Zanon, Bastianello, M., Pacico, J. \& C.S. Hutz, 2013. Relationships Between Positive and Negative Affect and The Five Factors of Personality in A Brazilian Sample. Paidéia, 23(56), pp. 285-292.

iii. Chênevert, D., Vandenberge, C. \& Trembla, M., 2014. Multiple Sources of Support, Affective Commitment, and Citizenship Behaviors. Personnel Review, 44(1), pp. 69-90.

iv. Chinomona, R., 2011. The Impact of Organizational Support On Work Spirituality, Organizational Citizenship Behaviour and Job Performance: The Case of Zimbabwe's Small and Medium Enterprises (SME) Sector. African Journal of Business Management, 6(36), pp. 10003-10014.

v. Choi, B. K., Moon, H., Ko, W. \& Kim, K., 2014. A Cross-Sectional Study of The Relationships Between Organizational Justices and OCB: Roles of Organizational Identification and Psychological Contracts. Leadership \& Organization Development Journal, 35(6), pp. 530554 .

vi. Dick, R. V. et al., 2008. Interactive Effects of Work Group and Organizational Identification On Job Satisfaction and Extra-role Behavior. Journal of Vocational Behaviour, Volume 72, pp. 388-399.

vii. $\quad$ F.Kazemipour, Amin, S. \& Pourseidi, B., 2012. Relationship Between Workplace Spirituality and Organizational Citizenship Behavior Among Nurses Through Mediation of Affective Organizational Commitment. Journal of Nursing Scholarship, 44(3), pp. 302-310.

viii. Goodman, J., 2002. Psychological Well-Being in the Jewish Community: The Impact of Social Identity and Spirituality, Kent State: Kent State University.

ix. Goris, J., Vaught, B. \& Pettit, J., 2000. Effects of Communication Direction On Job Performance and Satisfaction: A Moderated Regression Analysis. The Journal of Business Communication, 37(4), pp. 348-368.

x. Hair, J., Black, W., Babin, B. \& Anderson, R., 2010. Multivariate Data Analysis: A Global Perspective. s.l.:Pearson.

xi. Haryokusumo, D., 2015. Pengaruh Dimensi Spiritualitas Tempat Kerja Pada Komitmen Organisasional Dengan Dukungan Organisasional Persepsian Sebagai Variabel Pemoderasi, Yogyakarta: Universitas Gadjah Mada.

xii. He, H. \& Brown, A., 2013. Organizational Identity and Organizational Identification: A Review of the Literature and Suggestions for Future Research. Group \& Organization Management, 38(1), pp. 3-35.

xiii. Jena, R. \& Goswami, R., 2014. Measuring the Determinants of Organizational Citizenship Behaviour. Global Business Review, 15(2), pp. 381-396.

xiv. Jurkiewicz, C. \& Giacalone, R., 2004. A Values Framework for Measuring The Impact of Workplace Spirituality On Organizational Performance. Journal of Of Business Ethics, 49(2), pp. 129-142.

xv. Kane, R., Magnusen, M. \& Perrewé, P., 2012. Differential Effects of Identification on Extrarole Behavior. Career Development International, Volume 17, pp. 25-42.

xvi. Karanika-Murray, M., Duncan, N., Pontes, H. \& Griffiths, M., 2015. Organizational Identification, Work Engagement, and Job Satisfaction.. Journal of Managerial Psychology, 30(8), pp. 1019-1033. 
xvii. Kazemipour, F. \& Amin, S., 2012. The Impact of Workplace Spirituality Dimensions On Organisational Citizenship Behaviour Among Nurses with The Mediating Effect of Affective Organisational Commitment. Journal of Nursing Management, Volume 20, pp. 1039-1048.

xviii. Knippenberg, D. \& Sleebos, E., 2006. Organizational Identification Versus Organizational Commitment: Self-Definition, SocialExchange, and Job Attitudes. Journal of Organizational Behavior, 27(5), pp. 571-584.

xix. Mael, F. \& Ashforth, B., 1992. Alumni And Their Alma Mater: A Partial Test of The Reformulated Model of Organizational Identification. Journal of Organizational Behaviour, Volume 13, pp. 103-123.

xx. Meezenbroek, E. et al., 2012. Measuring Spirituality As A Universal Human Experience: A Review of Spirituality Questionnaires. Journal Relig Health, Volume 51, pp. 336-354.

xxi. Mishra, S. K., 2014. Linking Perceived Organizational Support to Emotional Labor. Personnel Review, Volume 43, pp. 845-860.

xxii. Nasurdin, A., Nejati, M. \& Mei, Y., 2013. Workplace Spirituality and Organizational Citizenship Behaviour: Exploring Gender As A Moderator. S.Afr.J.Bus.Manage, 44(1), pp. 6174.

xxiii. Paillé, P., 2015. Perceived Organizational Support and Work Outcomes. International Journal of Organizational Analysis, 23(2), pp. 191-212.

xxiv. Pandey, S., 2014. Workplace Spirituality: Linkages with Attitude, Mental Health, Leadership, Organizational Development, Earning Management, Stress and Well-being. he International Journal of Business \& Management, Volume 2, pp. 139-144.

xxv. Petchsawang, P. \& Duchon, D., 2009. Measuring Workplace Spirituality in An Asian Context. Human Resource Development International, 12(4), pp. 459-468.

xxvi. Petchsawang, P. \& Duchon, D., 2012. Workplace Spirituality, Meditation, and Work Performance. Journal of Management, Spirituality \& Religion, pp. 189-208.

xxvii. Podsakoff, P. et al., 2003. Common Method Biases in Behavioral Research: A Critical Review of the Literature and Recommended Remedies. Journal of Applied Psychology, 88(5), pp. 879-903.

xxviii. $\quad$ Podsakoff, P., MacKenzie, S., Paine, J. \& Bachrach, D., 200o. Organizational Citizenship Behaviors: A Critical Review of the Theoretical and Empirical Literature and Suggestions for Future Research. Journal of Management, 26(3), pp. 513-563.

xxix. Rhoades, L. \& Eisenberger, R., 2002. Perceived Organizational Support: A Review of the Literature. Journal of Applied Psychology, 87(4), pp. 698-714.

xxx. Safaria, T., Othman, A. \& M, N. W., 2010. Religious Coping, Job Insecurity and Job Stress among Javanese Academic Staff: A Moderated Regression Analysis. International Journal of Psychological Studies, 2(2), pp. 159-169.

xxxi. Tims, M., Bakker, A., D \& Derks, 2014. Daily Job Crafting and The Self-Efficacy-Performance Relationship. Journal of Managerial Psychology, 29(5), pp. 490-507.

xxxii. Vuori, T., San, E. \& Kira, M., 2012. Meaningfulness-making at Work. Qualitative Research in Organizations and Management: An International Journal, 7(2), pp. 231-248.

xxxiii. Weiss, H. \& Cropanzano, R., 1996. Affective Events Theory A Theoretical Discussion of The Structure, Causes and Consequences of Affective Experieces at Work. Research in Organizational Behavior, Volume 18, pp. 1-74.

xxxiv. Wirati, L., 2015. Pengaruh Konflik Pekerjaan-Keluarga pada keinginan Berpindah dengan Dukungan Organisasional Persepsian Sebagai Pemoderasi. Studi pada Karyawan PT. Bank X Cabang Surakarta, Jawa Tengah, Yogyakarta: Universitas Gadjah Mada. 